\title{
CONSUMERS AWARENESS TOWARDS GREEN MARKETING PRACTICES WITH REFERENCE TO \\ CONSUMER ELECTRONICS AND HOME APPLIANCES SECTOR
}

\author{
${ }^{1}$ Priyanka.P.Tarikar, ${ }^{2}$ Dr.A.N.Tamragundi, \\ ${ }^{1}$ Research Scholar, ${ }^{2}$ Professor \\ Department of Commerce, \\ $P G$ Department of studies in commerce, \\ Karnatak University, Dharwad, Karnataka, India
}

\begin{abstract}
:
Green marketing is a popular concept in today's marketing world as it emphasizes the use of eco-friendly tactics by various marketers in their campaigns. The researcher has attempted to study the awareness of consumers towards Green marketing practices by selecting consumer electronics and home appliances sector related to two products viz., Television and Refrigerators. For this purpose, a sample size of 400 respondents is drawn by employing stratified sampling techniques in Uttar Kannada district of Karnataka has been selected. Percentage technique was used to describe the demographic profile of the study area, and the Chi square test was used to determine whether there was a significant relationship between level of awareness and living place. The study's findings revealed that in the television product category, Green price, Green place and Green promotion have significant associations, whereas in the green product category, awareness of the ROHS phrase, recyclable labels, and eco-friendly packaging that benefits the environment has no significant association which denotes that level of awareness is ineffective in rural and urban areas. Further considering refrigerator product category, Green Price and Green place are significantly associated whereas in Green product it is found, awareness of adoption of $3 R$ 's by refrigerator brands, eco friendly ink used on product packages and Green promotion through internet, print and television media has no significant association. As a result, all companies marketing television and refrigerator brands must emphasize on environmentally features like ROHS compliance, environmentally friendly packaging involved in product, benefits of eco-friendly packages, adoption of 3R's (Reduce, Reuse, Recycle) by companies, Eco-friendly ink used for print on packages instead of just concentrating on offers/discount and product design.
\end{abstract}

Keywords: Consumer awareness, Green marketing practices, Television products, Refrigerator products. 


\section{Introduction:}

At present times, world is facing numerous problems with regard to environmental change. The environment has been affected significantly for meeting various requirements of people. Marketers have been showing their concern towards environment by adopting green technology for giving out the Eco-friendly products to consumers. All the stakeholders are showing their concern towards environment by taking various green initiatives. Even in Consumer durable industry, the marketers have adopted Green marketing practices for making some differences to environment. Consumer durable industry is considered as one of the most dynamic and fastest growing industries in Indian market, creating significant mark on human life and also considered to be one of the largest in the world. It has been transforming its business in an innovative way for meeting the various aspects of human population. It initiates growing demand for consumer durable goods in Indian market due to prime features like increasing disposable income and development of product technology.

Green marketing came into prominence in the late 1980's and early 1990's. When it was taken up for discussion, it was considered as marketing strategy focusing on development and marketing of products designed to minimize negative effects on the physical environment. It includes the study of all efforts to consume, produce, distribute, promote, package and reclaim products in a manner that is sensitive or responsible to ecological concerns. Today, Green Marketing has been adhered as one of the business practices by considering the consumers concern towards promoting, preserving and conserving the natural environment. The marketers in all sectors have responded quickly for overwhelming demand for environment friendly products in several ways, each of which consist as a part of green marketing. These includes a) Promoting the environmental attributes of products b) Introducing new products specifically for those concerned with energy efficiency, waste reduction, sustainability and c) Redesigning existing products with an eye towards these same consumers. It seems to be that Green Marketing cannot be considered as just one more approach to marketing but it has to be pursued as one of the additional dimensions to be involved in marketing field.

\section{Literature review:}

H. C. Purohit (2011) ${ }^{1}$ finds out the relationship between consumer attitude towards Green Marketing measured by covering all the basic concepts of marketing mix and their buying intention by considering price sensitivity and quality consciousness of consumers. The study utilizes five point Likert scale to measure consumer attitude with Green product which revealed that 89 percent 'strongly agree' and 96 percent 'agree' with the statement "Green products are valuable to society", with regard to price and promotional campaign, consumers are ready to pay more for those products and prefer those promotional campaign which protects the environment and distribution channels that causes less environmental pollution, but they are not ready to compromise with the quality of product for sake of environment.

Further the result confirms the findings that Price, Place and Promotion have significant relationship with buying intention of consumers whereas; Green products don't have significant relationship with buying intention of consumers. The author suggests to marketers 
that consumer attitude towards Green marketing should be measured and include in the marketing plan of the firms and communicated truthfully to consumers for achieving the goals and to fulfill social responsibility.

Sajal Kabiraj and R. C. Walke (2012) ${ }^{2}$ aimed to assess consumers' perception towards Green Marketing and Green products by selecting consumer preference from nongreen products to green products, consumer awareness, consumer preference in future and companies' green image as parameters for the research study. The study resulted in positive perception of consumers towards green marketing and green products in developing country like India. Analysis of study revealed that 77 percent of consumer preferences has shifted towards green products, 90 percent of consumers are more aware of environmental issues, 91 percent of consumers choose to prefer more for green products in future and 81 percent of companies with green image where able to gain distinctive advantage in the market place.

Manju Malik (2013) ${ }^{3}$ attempted to study the consumers and corporate awareness towards the concept of Green Marketing. To know the corporate awareness, author reviews the literature and highlights five reasons for firms going green. Firstly, due to organizations perceive environmental marketing as an opportunity for achieving their objectives, secondly, due to social responsibility, thirdly, due to Government pressure, fourthly, due to competitor's pressure and lastly, due to cost factor associated with waste disposal or reduction in material usage. Further the author has cited few examples of companies engaged in Green Marketing practices like lead free paint from Kansai Nerolac, Green channel counter by SBI, Green stadium in Delhi which conserves energy, eco-friendly rickshaws before CWG.

From the consumers point of view, the author finds that though Indian consumers are already aware and appreciate the importance of using green products(natural and herbal beauty products) even then there is need for a shift in the consumers behavior and attitude towards more environmentally friendly lifestyle. The author initiates that there is change happening but not happening quickly. Therefore, the marketers require putting up great efforts for doing Green marketing concept more happening in speedy way.

Sabita Mahapatra (2013) ${ }^{4}$ assesses the consumer awareness for green (certified) products and factors influencing their perception and willingness to purchase such products. For this purpose, five-point Likert scale and a six-point scale is utilized for study to measure the respondent's frequency of engaging in environmentally friendly behavior. Through the study it is found that majority of respondents appeared to be aware of green concept though there were some differences in understanding it. The respondents usually associated the term green product as reducing pollution, recycling waste, saving energy, promotion of conservation and corporate social responsibility. It further revealed that personal benefit, price, convenience in usage, performance, Availability, health and environmental concern were the factors which influenced them to purchase and pay more for green products.

Apporva Raval and Mamta Brahmbhatt (2014) ${ }^{\mathbf{5}}$ identifies the effectiveness of Green Marketing practices on consumer awareness about global warming, factors responsible for global warming, purchasing intention and barriers to purchase green consumer durables (Electronics, Household Appliances, Automobiles) as the parameters for study in Gujarat region of India. The study tries to find out whether there is difference in purchasing criteria for 
consumer durable among different industries by adopting ANOVA test. The researcher gets to know that majority of consumers are aware about global warming and its harmful effects of environmental changes on human being. It is perceived that human activities like creating smoke as one of the biggest reasons for environmental harm followed by throwing chemicals and gases, throwing solid wastes and wasting natural resources.

The consumers show positive intention to buy and pay more for green consumer durable and contribute to create awareness by word of mouth, but some factors like difficulty to buy, poor performance, high price pose as barrier to their purchase. The study concludes and proves that there was significant difference for purchasing criteria of eco-friendliness, colour and stand mark for green products, whereas purchasing criteria for appearance, price, quality, Brand, Package and labelling, variety, service and need fulfillment for green consumer durables showed no significant difference among different industries.

\section{Statement of the research problem:}

Through literature review, it is found that limited research is done on studying the awareness level of consumers towards Green marketing practices related to its 4 P's in Consumer Electronics and Home Appliances sector in India. Therefore, the researcher wants to know awareness of consumers in Consumer Electronics and Home Appliances sector as it will benefit the marketer to know extent of consumer awareness towards Green Product, Green Price, Green Place and Green Promotion practices adopted by them so that if required adequate measures can be undertaken by marketers as Consumers are described as "Kings of market".

\section{Objectives of the study:}

The following are the objectives undertaken for study:

1. To evaluate the Consumer level of awareness towards Green Marketing Practices under television and Refrigerator product category.

2. To study significant association between level of awareness and living place towards Green Marketing Practices related to 4 P's of marketing under television product category.

3. To study significant association between level of awareness and living place towards Green Marketing Practices related to 4 P's of marketing under Refrigerator product category.

\section{Hypothesis of the study:}

Following are the hypothesis used for the study based on Primary data related to level of consumer awareness towards Green Marketing practices:

$\mathrm{H}_{01}$ : There is no significant association between level of awareness and living place towards Green Marketing practices under television product category.

$\mathrm{H}_{02}$ : There is no significant association between level of awareness and living place towards Green Marketing practices under Refrigerator product category. 


\section{Research Methodology:}

\section{a. Sources of data:}

Collection of research data has been done through Primary sources. Primary data is utilized for studying level of consumer awareness towards Consumer Electronics and Home Appliance products selected for study. For this purpose, Survey method is adopted by constructing well Structured questionnaires in close ended form. Respondents were personally met by researcher. Respondents are considered on basis of various demographic variables by drawing a sample size of 400 respondents from Uttar Kannada district of Karnataka state by employing Stratified sampling technique. Uttar Kannada district is considered as largest district in state of Karnataka with eleven talukas marked for beauty of greenery. According to Karnataka Census report 2011, the population size of Uttar Kannada district is 14,37,169. The main traditional occupations are agriculture, Fisheries, Animal Husbandry, Sericulture, Horticulture, Beekeeping and Leather works etc.

To draw sample size out of 14,37,169 total population in Uttar Kannada district of Karnataka State, the study has utilized Yamane (1967) simplified formula for calculation of sample size which is shown below:

$$
\mathbf{n}=\frac{\mathrm{N}}{1+\mathrm{N}(\mathrm{e} 2)}
$$

Where, $\mathrm{N}$ is the population size

$\mathrm{e}$ is the level of precision

According to him, for a $95 \%$ confidence level and $\mathrm{p}=0.5$, size of the sample will be 400 respondents.

\section{b. Sample Description:}

Consumer durable industry is diversified sector comprising various segments so it is hardly possible to concentrate on all sectors, for this purpose the study selected Consumer Electronics and Home Appliances sector as it is considered to be major contributor towards country's economic growth and also large number of consumer groups are attracted towards this sector as they require and utilize these products in their daily life. therefore; two product categories are selected as they are considered to be required products at present times viz., Television and Refrigerators. On basis of these products, the researcher tries to know level of consumer awareness towards Green Marketing practices.

\section{c. Tools and Techniques:}

To analyze and test the primary data, statistical tool and techniques like five-point Likert scale, Percentage method and Chi Square test are been utilized for studying the Level of awareness towards Green Marketing Practices in Consumer Electronics and Home Appliances products. Further, Specific computer software like MS-excel, SPSS statistics 20 version has been applied for computing the data. 


\section{Scope of the study:}

The study focuses on studying consumer level of awareness towards Green Marketing Practices in Consumer Electronics and Home Appliances Companies with specific products selected for study viz., Television and Refrigerator. The study concentrates on 4P's of Green Marketing mix. The study has been carried out in selected area of Uttar Kannada district, Karnataka. The study area is selected on the basis of total population of Uttar Kannada District.

\section{Limitations of the study:}

There is wide range of products in Consumer Electronics and Home Appliances Companies. So, the products are limited to two products that includes Television and Refrigerator that are widely used by consumers in their daily lives. The researcher has considered these products as it will be easy for consumers to answer the questions because they deal with these products in their day-to-day life. Primary data is restricted to Uttar Kannada District of Karnataka State with a sample size of Four hundred respondents.

\section{ANALYSIS AND INTERPRETATIONS:}

\section{Demographic profile of respondents:}

Table 1 highlights the demographic profile of consumers for studying their awareness level in consumer electronics and home appliances sector. The study has totally considered nine demographic factors viz., Gender, Qualification, Occupation, Age, Marital status. wherein comparison between rural and urban area.

Table 1: Respondent's demographic profile

\begin{tabular}{|c|c|c|c|c|}
\hline $\begin{array}{l}\text { Demographic } \\
\text { factors }\end{array}$ & Variables & Rural & Urban & Total \\
\hline \multirow{3}{*}{ Gender } & Male & $\begin{array}{c}99(48) \\
(52)\end{array}$ & $\begin{array}{c}109(52) \\
(52)\end{array}$ & $\begin{array}{c}208(100) \\
\quad(52)\end{array}$ \\
\hline & Female & $\begin{array}{c}93(48) \\
(48)\end{array}$ & $\begin{array}{c}99(52) \\
(48)\end{array}$ & $\begin{array}{c}192(100) \\
(48)\end{array}$ \\
\hline & Total & $\begin{array}{c}192(48) \\
(100)\end{array}$ & $\begin{array}{c}208(52) \\
(100)\end{array}$ & $\begin{array}{c}400(100) \\
(100)\end{array}$ \\
\hline \multirow{5}{*}{ Qualification } & School level & $\begin{array}{c}43(63) \\
(22)\end{array}$ & $\begin{array}{c}25(37) \\
(12)\end{array}$ & $\begin{array}{c}68(100) \\
(17)\end{array}$ \\
\hline & Graduate & $\begin{array}{c}68(46) \\
(35)\end{array}$ & $\begin{array}{c}81(54) \\
(39)\end{array}$ & $\begin{array}{c}149(100) \\
(37)\end{array}$ \\
\hline & Post Graduate & $\begin{array}{c}57(45) \\
(30)\end{array}$ & $\begin{array}{c}70(55) \\
(34)\end{array}$ & $\begin{array}{c}127(100) \\
(32)\end{array}$ \\
\hline & Professional & $\begin{array}{c}24(43) \\
(13)\end{array}$ & $\begin{array}{c}32(57) \\
(15)\end{array}$ & $\begin{array}{c}56(100) \\
(14)\end{array}$ \\
\hline & Total & $\begin{array}{c}192(48) \\
(100)\end{array}$ & $\begin{array}{c}208(52) \\
(100)\end{array}$ & $400(100)$ \\
\hline \multirow[t]{2}{*}{ Occupation } & Agriculturist & $\begin{array}{c}32(55) \\
(17)\end{array}$ & $\begin{array}{c}26(45) \\
(13)\end{array}$ & $\begin{array}{c}58(100) \\
(15)\end{array}$ \\
\hline & Housewife & $17(41)$ & $24(59)$ & $41(100)$ \\
\hline
\end{tabular}




\begin{tabular}{|c|c|c|c|c|}
\hline & & (09) & (12) & (10) \\
\hline & $\begin{array}{l}\text { Government } \\
\text { employee }\end{array}$ & $\begin{array}{c}28(44) \\
(15)\end{array}$ & $\begin{array}{c}36(56) \\
(17)\end{array}$ & $\begin{array}{c}64(100) \\
(16)\end{array}$ \\
\hline & Private employee & $\begin{array}{c}37(47) \\
(19)\end{array}$ & $\begin{array}{c}41(53) \\
(20)\end{array}$ & $\begin{array}{c}78(100) \\
(20)\end{array}$ \\
\hline & Business person & $\begin{array}{c}49(51) \\
(26)\end{array}$ & $\begin{array}{c}48(49) \\
(23)\end{array}$ & $\begin{array}{c}97(100) \\
(24)\end{array}$ \\
\hline & Others & $\begin{array}{c}29(47) \\
(15)\end{array}$ & $\begin{array}{c}33(53) \\
(16)\end{array}$ & $\begin{array}{c}62(100) \\
(16)\end{array}$ \\
\hline & Total & $\begin{array}{c}192(48) \\
(100)\end{array}$ & $\begin{array}{c}208(52) \\
(100)\end{array}$ & $\begin{array}{c}400(100) \\
(100)\end{array}$ \\
\hline \multirow{5}{*}{ Age } & 21 to 30 years & $\begin{array}{c}08(73) \\
(04)\end{array}$ & $\begin{array}{c}03(27) \\
(01)\end{array}$ & $\begin{array}{c}11(100) \\
(03)\end{array}$ \\
\hline & 31 to 40 years & $\begin{array}{c}84(49) \\
(44)\end{array}$ & $\begin{array}{c}87(51) \\
(42)\end{array}$ & $\begin{array}{c}171(100) \\
(43)\end{array}$ \\
\hline & 41 to 50 years & $\begin{array}{c}63(46) \\
(33)\end{array}$ & $\begin{array}{c}73(54) \\
(35)\end{array}$ & $\begin{array}{c}136(100) \\
(34)\end{array}$ \\
\hline & 51 years and above & $\begin{array}{c}37(45) \\
(19)\end{array}$ & $\begin{array}{c}45(55) \\
(22)\end{array}$ & $\begin{array}{c}82(100) \\
(20)\end{array}$ \\
\hline & Total & $\begin{array}{c}192(48) \\
(100)\end{array}$ & $\begin{array}{c}208(52) \\
(100)\end{array}$ & $\begin{array}{c}400(100) \\
(100)\end{array}$ \\
\hline \multirow{3}{*}{ Marital status } & Married & $\begin{array}{c}160(52) \\
(83)\end{array}$ & $\begin{array}{c}148(48) \\
(71)\end{array}$ & $\begin{array}{c}308(100) \\
(77)\end{array}$ \\
\hline & Unmarried & $\begin{array}{c}32(35) \\
(17)\end{array}$ & $\begin{array}{c}60(65) \\
(29)\end{array}$ & $\begin{array}{c}92(100) \\
(23)\end{array}$ \\
\hline & Total & $\begin{array}{c}192(48) \\
(100)\end{array}$ & $\begin{array}{c}208(52) \\
(100)\end{array}$ & $\begin{array}{c}400(100) \\
(100)\end{array}$ \\
\hline
\end{tabular}

Source: Field survey

Note: Figures in parenthesis shows row and column percentages

Table 1 presents the respondents demographic profile in rural and urban areas. Out of total 192 rural and 208 urban respondents, Gender wise, majority 52 percent of rural and urban respondents are male compared to female respondents. On qualification basis, majority 35 percent of rural respondents and 37 percent of urban respondents belong to graduate group. On occupation basis, majority 20 percent of rural respondents and 23 percent of urban respondents belong to businessperson group. On age basis, majority 44 percent of rural respondents and 42 percent of urban respondents belong to 31 to 40 age group, On basis of marital status, 83 percent of rural respondents and 71 percent of urban respondents belong to married group.

\section{Respondent's level of awareness of green marketing practices towards product categories selected for study:}

Awareness signifies alertness of consumers towards the information provided by the marketers related to its product. The table no. 2 to table no. 5 represents respondents level of awareness towards green marketing practices related to two product categories selected for the study. Five-point Likert scale marked with 5 to 1 level has been utilised which signifies as 5 Extremely aware, 4- Moderately aware, 3 - Somewhat aware, 2- Slightly aware, 1 - Not at all aware. 
Table 2: Statement assigned with codes on awareness of Green Marketing Practices towards television product

\begin{tabular}{|c|c|}
\hline Statements & Codes \\
\hline \multicolumn{2}{|l|}{ Green product } \\
\hline Aware of television product having environment friendly features. & Q1 \\
\hline $\begin{array}{l}\text { Strategy of source reduction for packaging of television product will benefit to } \\
\text { minimize unnecessary wastages for packaging. }\end{array}$ & Q2 \\
\hline $\begin{array}{l}\text { Light weighted television products benefit to save material source thereby reducing the } \\
\text { carbon emissions. }\end{array}$ & Q3 \\
\hline Knowledge about smarter technologies involved in television product. & Q4 \\
\hline Aware of 3 R's adopted by companies of various television brands. & Q5 \\
\hline Aware of energy star labels used by various television brands. & Q6 \\
\hline $\begin{array}{l}\text { Aware of ROHS phrase used on product manuals by various television Brands. } \\
\text { Rörs }\end{array}$ & Q7 \\
\hline Aware of recyclable labels used on product packages by various television brands. & Q8 \\
\hline $\begin{array}{l}\text { Aware of waste disposal symbol used on product packages by various television } \\
\text { brands }\end{array}$ & Q9 \\
\hline Aware of television brands using recycled content for their product manuals. & Q10 \\
\hline Aware of eco-friendly ink use for prints on packages by various television brands. & Q11 \\
\hline Environment friendly packaging of television benefits to environment. & Q12 \\
\hline \multicolumn{2}{|l|}{ Green price } \\
\hline Aware about the prices charged for various television brands. & Q13 \\
\hline $\begin{array}{l}\text { I know higher price means involvement of more environmental features into television } \\
\text { product. }\end{array}$ & Q14 \\
\hline \multicolumn{2}{|l|}{ Green place } \\
\hline $\begin{array}{l}\text { Aware about the places for availability of television product having environment } \\
\text { friendly feature. }\end{array}$ & Q15 \\
\hline $\begin{array}{l}\text { Aware about the pollution free distribution channels adopted by various television } \\
\text { brands. }\end{array}$ & Q16 \\
\hline \multicolumn{2}{|l|}{ Green promotion } \\
\hline $\begin{array}{l}\text { Understand the information made available by television brands on its product } \\
\text { packages. }\end{array}$ & Q17 \\
\hline $\begin{array}{l}\text { Awareness of television product with environment friendly features is possible through } \\
\text { internet compared to print and television media. }\end{array}$ & Q18 \\
\hline $\begin{array}{l}\text { I am knowledgeable about the green corporate image created by companies through } \\
\text { advertisement of television product with environmental features. }\end{array}$ & Q19 \\
\hline $\begin{array}{l}\text { Companies are providing information about television product having environmental } \\
\text { features. }\end{array}$ & Q20 \\
\hline
\end{tabular}


Table 3: Significant association between level of awareness and living place towards Green Marketing Practices under television products

\begin{tabular}{|c|c|c|c|c|c|}
\hline Statements & $\begin{array}{c}\text { Chi-Square } \\
\text { value }\end{array}$ & $P$ value & DF & Result & $\begin{array}{c}\text { Remarks on } \\
\text { Null } \\
\text { hypothesis }\end{array}$ \\
\hline \multicolumn{6}{|l|}{ Green Product } \\
\hline $\mathrm{Q} 1$ & 50.571 & .000 & 04 & Significant & Reject \\
\hline Q2 & 40.258 & .000 & 04 & Significant & Reject \\
\hline Q3 & 39.780 & .000 & 04 & Significant & Reject \\
\hline Q4 & 20.076 & .000 & 04 & Significant & Reject \\
\hline Q5 & 57.076 & .000 & 04 & Significant & Reject \\
\hline Q6 & 15.164 & .004 & 04 & Significant & Reject \\
\hline Q7 & 4.172 & .383 & 04 & Not significant & Accept \\
\hline Q8 & 6.668 & .154 & 04 & Not significant & Accept \\
\hline Q9 & 27.105 & .000 & 04 & Significant & Reject \\
\hline Q10 & 98.852 & .000 & 04 & Significant & Reject \\
\hline Q11 & 29.514 & .000 & 04 & Significant & Reject \\
\hline Q12 & 7.701 & .103 & 04 & Not significant & Accept \\
\hline \multicolumn{6}{|l|}{ Green Price } \\
\hline Q13 & 29.050 & .000 & 04 & Significant & Reject \\
\hline Q14 & 68.395 & .000 & 04 & Significant & Reject \\
\hline \multicolumn{6}{|l|}{ Green Place } \\
\hline Q15 & 52.392 & .000 & 04 & Significant & Reject \\
\hline Q16 & 20.692 & .000 & 04 & Significant & Reject \\
\hline \multicolumn{6}{|c|}{ Green Promotion } \\
\hline Q17 & 25.918 & .000 & 03 & Significant & Reject \\
\hline Q18 & 19.441 & .001 & 04 & Significant & Reject \\
\hline Q19 & 43.654 & .000 & 04 & Significant & Reject \\
\hline Q20 & 44.218 & .000 & 04 & Significant & Reject \\
\hline
\end{tabular}

Significance level at $0.05 \quad$ Source: Field survey

5 - Extremely aware, 4 - Moderately aware, 3 - Somewhat aware, 2-Slightly aware, 1 - Not at all aware

Table 3 reveals the association between level of awareness and living place towards green marketing practices under television product for which twenty statements have been selected.

Codes with Q1 revealing awareness of television product having environment friendly features has computed chi square value 50.571. The p-value for computed chi square value is $.000(<0.05)$ which is less than significance level. Hence, there is significant association.

Code with Q2 stating awareness about the strategy of source reduction involved in packing television product that minimize unnecessary wastages has computed chi square value 40.258. The p-value for computed chi square value is $.000(<0.05)$ which is less than significance level. Hence, there is significant association. 
Code with Q3 denoting light weighted television products benefits to save material source thereby reducing the carbon emissions has computed chi square value 39.780 . The pvalue for computed chi square value is $.000(<0.05)$ which is less than significance level. Hence, there is significant association.

Code with Q4 states knowledge about smarter technologies involved in television product has computed chi square value 20.076. The $\mathrm{p}$-value for computed chi square value is $.000(<0.05)$ which is less than significance level. Hence, there is significant association.

Code with Q5 stating awareness of 3 R's adopted by companies of various television brands has computed chi square value 57.076. The $\mathrm{p}$-value for computed chi square value is $.000(<0.05)$ which is less than significance level. Hence, there is significant association.

Code with Q6 denoting awareness of energy star labels used by various television brands has computed chi square value 15.164. The p-value for computed chi square value is $.004(<0.05)$ which is less than significance level. Hence, there is significant association.

Code with Q7 stating awareness of ROHS phrase used on product manuals by various television brands has computed chi square value 4.172. The p-value for computed chi square value is $.383(<0.05)$ which is more than significance level. Hence, there is no significant association.

Code with Q8 denoting aware of recyclable labels used on product packages by various television brands has computed chi square value 6.668. The p-value for computed chi square value is $.154(<0.05)$ which is more than significance level. Hence, there is no significant association.

Code with Q9 denoting aware of waste disposal symbolized on product packages by various television brands has computed chi square value 27.105. The p-value for computed chi square value is $.000(<0.05)$ which is less than significance level. Hence, there is significant association.

Code with Q10 awareness of television brads using recycled content for their product manuals has computed chi square value 98.852. The $\mathrm{p}$-value for computed chi square value is $.000(<0.05)$ which is less than significance level. Hence, there is significant association.

Code with Q11 denoting aware of eco-friendly ink use for prints on packages by various television brands has computed chi square value 29.514. The p-value for computed chi square value is $.000(<0.05)$ which is less than significance level. Hence, there is significant association.

Code with Q12 Environment friendly packaging of television benefits to environment has computed chi square value 7.701. The p-value for computed chi square value is .103 $(<0.05)$ which is more than significance level. Hence, there is no significant association.

Code with Q13 awareness about the prices charged for various television brands Q13 awareness about the prices charged for various television brands has computed chi square value 29.050. The p-value for computed chi square value is $.000(<0.05)$ which is less than significance level. Hence, there is significant association.

Code with Q14 stating awareness of higher price involved in television product having environment friendly features has computed chi square value 68.395. The p-value for computed chi square value is $.000(<0.05)$ which is less than significance level. Hence, there is significant association. 
Code with Q15 stating awareness about the places for availability of television product having environment friendly feature has computed chi square value 52.392. The p-value for computed chi square value is .000 $(<0.05)$ which is less than significance level. Hence, there is significant association.

Code with Q16 showing aware about the pollution free distribution channels adopted by various television brands has computed chi square value 20.692. The p-value for computed chi square value is $.000(<0.05)$ which is less than significance level. Hence, there is significant association.

Code with Q 17 denoting understand of information made available by television brands on its product packages has computed chi square value 25.918. The p-value for computed chi square value is $.000(<0.05)$ which is less than significance level. Hence, there is significant association.

Code with Q18 awareness of television products with environment friendly feature is possible through internet compared to print and television media has computed chi square value 19.441. The p-value for computed chi square value is .001 $(<0.05)$ which is less than significance level. Hence, there is significant association.

Code with Q19 denoting knowledge about the green corporate image created by companies through advertisement of television product with environmental features has computed chi square value 43.654. The p-value for computed chi square value is $.000(<0.05)$ which is less than significance level. Hence, there is significant association.

Code with Q20 aware about companies providing information about television product having environmental features has computed chi square value 44.218. The p-value for computed chi square value is $.000(<0.05)$ which is less than significance level. Hence, there is significant association.

Table 4: Statement assigned with codes on awareness of Green Marketing Practices towards Refrigerator product.

\begin{tabular}{|l|c|}
\hline \multicolumn{1}{|c|}{ Statements } & Codes \\
\hline Green product & Q1 \\
\hline Aware of refrigerator product having all environment friendly features. & Q2 \\
\hline $\begin{array}{l}\text { Strategy of source reduction for packaging of refrigerator products will benefit to } \\
\text { minimize unnecessary wastages for packaging. }\end{array}$ & Q3 \\
\hline Aware about various eco-friendly refrigerant used by different refrigerator brands. & Q4 \\
\hline Knowledge about smarter technologies involved in refrigerator product. & Q5 \\
\hline $\begin{array}{l}\text { Aware of adoption of 3R's by various referigerator brands. } \\
\text { Brands. }\end{array}$ & Q6 \\
\hline $\begin{array}{l}\text { Aware of ROHS phrase used on products and product manuals by various } \\
\text { refrigerator brands }\end{array}$ & Q7 \\
\hline $\begin{array}{l}\text { Aware of recyclable labels used on product packages by various refrigerator } \\
\text { brands. }\end{array}$ & Q8 \\
\hline
\end{tabular}




\begin{tabular}{|c|c|}
\hline $\begin{array}{l}\text { Aware of waste disposal symbol and instructions used on product packages by } \\
\text { various refrigerator brands. }\end{array}$ & Q9 \\
\hline Aware of refrigerator brands using recycled content for their product manuals. & Q10 \\
\hline Aware of eco-friendly ink use for prints on packages by various refrigerator brands. & Q11 \\
\hline Environment friendly packaging of refrigerator products benefits the environment. & Q12 \\
\hline \multicolumn{2}{|l|}{ Green price } \\
\hline Aware about the prices charged for various refrigerator brands. & Q13 \\
\hline $\begin{array}{l}\text { I consider higher price means involvement of more environmental features into } \\
\text { refrigerator product. }\end{array}$ & Q14 \\
\hline \multicolumn{2}{|l|}{ Green place } \\
\hline $\begin{array}{l}\text { Aware about the places for availability of refrigerator product having environment } \\
\text { friendly feature. }\end{array}$ & Q15 \\
\hline $\begin{array}{l}\text { Aware about the pollution free distribution channels adopted by various } \\
\text { refrigerator brands. }\end{array}$ & Q16 \\
\hline \multicolumn{2}{|l|}{ Green Promotion } \\
\hline $\begin{array}{l}\text { Understand the information made available by refrigerator brands on its product } \\
\text { packages. }\end{array}$ & Q17 \\
\hline $\begin{array}{l}\text { Awareness of refrigerator products with environment friendly features is possible } \\
\text { through internet compared to print and television media. }\end{array}$ & Q18 \\
\hline $\begin{array}{l}\text { I am knowledgeable about the green corporate image created by companies through } \\
\text { advertising of refrigerator product with environmental features. }\end{array}$ & Q19 \\
\hline $\begin{array}{l}\text { Companies are providing information about refrigerator product having } \\
\text { environmental features. }\end{array}$ & Q20 \\
\hline
\end{tabular}

Table 5: Significant association between level of awareness and living place towards Green Marketing Practices under Refrigerator products.

\begin{tabular}{|c|c|c|c|c|c|}
\hline Statements & $\begin{array}{c}\text { Calculated } \\
\text { value }\end{array}$ & $\begin{array}{c}\text { P } \\
\text { value }\end{array}$ & $\begin{array}{c}\text { Degree of } \\
\text { freedom }\end{array}$ & Result & $\begin{array}{c}\text { Remarks on } \\
\text { Null hypothesis }\end{array}$ \\
\hline Green Product \\
\hline Q1 & 20.713 & .000 & 04 & Significant & Reject \\
\hline Q2 & 41.023 & .000 & 04 & Significant & Reject \\
\hline Q3 & 31.230 & .000 & 04 & Significant & Reject \\
\hline Q4 & 32.929 & .000 & 04 & Significant & Reject \\
\hline Q5 & 2.573 & .632 & 04 & Not significant & Accept \\
\hline Q6 & 32.992 & .000 & 04 & Significant & Reject \\
\hline Q7 & 15.481 & .004 & 04 & Significant & Reject \\
\hline Q8 & 75.317 & .000 & 04 & Significant & Reject \\
\hline Q9 & 31.072 & .000 & 04 & Significant & Reject \\
\hline Q10 & 36.762 & .000 & 04 & Significant & Reject \\
\hline Q11 & 8.580 & .073 & 04 & Not significant & Accept \\
\hline
\end{tabular}




\begin{tabular}{|c|c|c|c|c|c|}
\hline Q 12 & 34.701 & .000 & 04 & Significant & Reject \\
\hline Green Price & 45.192 & .000 & 04 & Significant & Reject \\
\hline Q 13 & 62.237 & .000 & 04 & Significant & Reject \\
\hline Q 14 & 42.949 & .000 & 04 & Significant & Reject \\
\hline Green Place & .000 & 04 & Significant & Reject \\
\hline Q 15 & 40.834 & & & Reject \\
\hline Q 16 & 13.110 & .011 & 04 & Significant & Accept \\
\hline Green Promotion & 5.329 & .264 & 04 & Not significant & Reject \\
\hline Q 17 & 45.238 & .000 & 04 & Significant & Reject \\
\hline Q 18 & 44.758 & .000 & 04 & Significant &
\end{tabular}

Significance level at 0.05

Source: Field survey

5 - Extremely aware, 4 - Moderately aware, 3 - Somewhat aware, 2- Slightly aware, 1 - Not at all aware

Table 5 reveals the level of awareness towards green marketing practices under refrigerator product for which twenty statements have been selected. Codes with Q1 revealing awareness of refrigerator product having environment friendly features has computed chi square value 20.713. The p-value for computed chi square value is .000 $(<0.05)$ which is less than significance level. Hence, there is significant association.

Code with Q2 stating awareness about the strategy of source reduction involved in packing refrigerator product that minimize unnecessary wastages has computed chi square value 41.023. The p-value for computed chi square value is .000 $(<0.05)$ which is less than significance level. Hence, there is significant association.

Code with Q3 stating awareness about various eco-friendly refrigerant used by different refrigerator brands has computed chi square value 31.230. The p-value for computed chi square value is $.000(<0.05)$ which is less than significance level. Hence, there is significant association.

Code with Q4 states knowledge about smarter technologies involved in refrigerator product has computed chi square value 32.929. The $\mathrm{p}$-value for computed chi square value is $.000(<0.05)$ which is less than significance level. Hence, there is significant association.

Code with Q5 stating awareness of 3 R's adopted by companies of various brands has computed chi square value 2.573 . The p-value for computed chi square value is $.632(<0.05)$ which is more than significance level. Hence, there is no significant association.

Code with Q6 denoting awareness of energy star labels used by various brands has computed chi square value 32.992. The p-value for computed chi square value is $.000(<0.05)$ which is more than significance level. Hence, there is significant association.

Code with Q7 stating awareness of ROHS phrase used on product manuals by various brands has computed chi square value 15.481. The p-value for computed chi square value is $.004(<0.05)$ which is less than significance level. Hence, there is significant association. 
Code with Q8 denoting aware of recyclable labels used on product packages by various brands has computed chi square value 75.317. The p-value for computed chi square value is $.000(<0.05)$ which is less than significance level. Hence, there is significant association.

Code with Q9 denoting aware of waste disposal symbol used on product packages by various brands has computed chi square value 31.072. The p-value for computed chi square value is $.000(<0.05)$ which is less than significance level. Hence, there is significant association.

Code with Q10 awareness of refrigerator brands using recycled content for their product manuals has computed chi square value 36.762. The p-value for computed chi square value is $.000(<0.05)$ which is less than significance level. Hence, there is significant association.

Code with Q11 denoting aware of eco-friendly ink use for prints on packages by various brands has computed chi square value 8.580 . The $\mathrm{p}$-value for computed chi square value is .073 $(<0.05)$ which is more than significance level. Hence, there is no significant association.

Code with Q12 Environment friendly packaging of refrigerator benefits to environment has computed chi square value 34.701. The p-value for computed chi square value is .000 $(<0.05)$ which is less than significance level. Hence, there is significant association.

Code with Q13 awareness about the prices charged for various brands has computed chi square value 45.192. The p-value for computed chi square value is $.000(<0.05)$ which is less than significance level. Hence, there is significant association.

Code with Q14 stating awareness of higher price involved in refrigerator product having environment friendly features has computed chi square value 62.237. The p-value for computed chi square value is $.000(<0.05)$ which is less than significance level. Hence, there is significant association.

Code with Q15 stating awareness about the places for availability of refrigerator product having environment friendly feature has computed chi square value 42.949. The pvalue for computed chi square value is $.000(<0.05)$ which is less than significance level. Hence, there is significant association.

Code with Q16 showing aware about the pollution free distribution channels adopted by various brands has computed chi square value 40.834 . The p-value for computed chi square value is $.000(<0.05)$ which is less than significance level. Hence, there is significant association.

Code with Q 17 denoting understand of information made available by refrigerator brands on its product packages has computed chi square value 13.110. The p-value for computed chi square value is .011 $(<0.05)$ which is less than significance level. Hence, there is significant association.

Code with Q18 awareness of refrigerator products with environment friendly feature is possible through internet compared to print and television media, has computed chi square value 5.329. The p-value for computed chi square value is $.264(<0.05)$ which is more than significance level. Hence, there is no significant association.

Code with Q19 denoting knowledge about the green corporate image created by companies through advertisement of refrigerator product with environmental features has computed chi square value 45.238. The p-value for computed chi square value is $.000(<0.05)$ which is less than significance level. Hence, there is significant association. 
Code with Q20 aware about companies providing information about refrigerator product having environmental features has computed chi square value 44.758. The p-value for computed chi square value is .000 $(<0.05)$ which is less than significance level. Hence, there is significant association.

\section{Findings:}

Respondents' awareness towards green marketing practices under television and refrigerator product categories to know significant association between awareness towards green marketing practices and living place, it found that:

- Television: - Green product practices Codes with Q1 to Q12 has significant association except Q7 denoting awareness towards ROHS phrase, Q8 denoting awareness towards recyclable labels and Q12 denoting awareness about environmentally friendly packaging of television benefit to environment has no significant association which means awareness is ineffective in rural and urban areas related to these statements. In case of green price, Green Place and Green Promotion there is significant association.

- Refrigerator - Green product practices Codes with Q1 to Q12 has significant association except Q5 denoting awareness of adoption of 3 R's by various refrigerator brands and Q11 denoting awareness of eco-friendly ink used for prints on packages by various refrigerator brands are not significantly associated which means awareness and living place are independent factors which reveals ineffectiveness of awareness level in rural and urban areas related to this statements. In case of Green Price, and Green Place there is significant association. In Green promotion Q17 to Q20 has significant association except Q18 denoting awareness of refrigerator products with environment friendly features is possible through internet compared to print and television media has not significant association.

\section{Suggestions:}

All the companies marketing television and refrigerator brands have to highlight on environmentally features like ROHS compliance, environmentally friendly packaging involved in product, benefits of eco-friendly packages, adoption of 3R's (Reduce, Reuse, Recycle) by companies, Eco-friendly ink used for print on packages instead of just concentrating on offers/discount and product design.

\section{Conclusion:}

Green marketing is very prominent across the countries as whole country is well aware about the consequences that has resulted to climate change. In India Green marketing needs to go much further though the marketers have taken green practices or awareness of consumers exist but legal framework are required to be designed and implemented in systematic form. The study has focused on consumer awareness towards green marketing practices in selected sample units, where the majority of respondents are male belonging to graduate group having majorly business as its occupation under the age category of 31 to 40 years under the married group. The income of family lies in lower income level having two earning members. Awareness level of respondents both in rural and urban area showed that consumers are not significantly aware of ROHS, recyclable level and ecofriendly packaging used for television. 
In refrigerator product, consumers are not significantly aware of adoption of $3 \mathrm{Rs}$, eco-friendly ink used on product packages, advertisement initiated in televise and print media. To conclude, Consumers are aware and have purchased the product that involves eco design practices, green packaging and labelling practices and green advertising practices but they don't understand the green attributes involved in the products for some attributes therefore companies have to take demonstrate the product feature that has green attributes at maximum level.

\section{References:}

1. H. C. Purohit (2011), "Consumer buying behavior of green products ", The international Journal of Research in Commerce, Economics and Management, Vol. 1, issue 1, pp 94-97.

2. Sajal Kabiraj and R. C. Walke (2012), "Green marketing practices: Understanding consumer preferences in an Indian perspective", International Journal for Management Research, Vol. 2(1).

3. Manju Malik (2013), "A study of increasing awareness among organizations and consumers towards green marketing”, International Journal Of marketing, Financial Services and Management Research, Vol. 2, No.5, pp 17-25.

4. Sabita Mahapatra (2013), "A study on consumer's perception for green products: An empirical study from India”, International Journal of Management and Information Technology, Vol.7. No.1, pp 924-933.

5. Apporva Raval and Mamta Brahmbhatt (2014), "A study of the awareness, perception and purchasing criteria of green consumer durable products in Gujarat", Journal of Radix International Educational and Research Consortium, Vol. 3, issue 12, pp 32-39.

\section{Books:}

- Robert Dahlstrom. "Green marketing - Theory, Practice and Strategies", Cengage Learning India private limited, Delhi, India, 2011.

- Jacquelyn A. Ottman, "The new rules of Green marketing - Strategies, tools and inspiration for sustainable branding”, Greenleaf publishing limited, United Kingdom, 2011.

- Jacquelyn A. Ottman, "Green marketing - Challenges and opportunities for the New marketing age”, NTC business books, 1993.

- Wayne D.Hoyer and Deborah J.Maclnnis, "Consumer behaviour”, All India publishers and Distributors, Chennai, India 1999.

- D.R.Palekar and P T Pattanshetty, "Marketing Management - A basic approach", R.Chand \& Co., publish house, New Delhi, India, 1997.

\section{Reports and Publications:}

- Annual reports of Ministry of Electronics and information technology.

- IBEF reports on Indian Consumer durable industry.

- TV veopar journal. 